\title{
IKT-eszközök használata óvodás korban - Egy kérdőív nyílt tételeinek kódolása EKOD-makrócsomaggal
}

\author{
B. Németh Mária ${ }^{1}$, Juhász Fruzsina ${ }^{2}$, Hódi Ágnes ${ }^{3}$ és Tóth Edit \\ ${ }^{1}$ SZTE BTK Neveléstudományi Intézet Pedagógiai Értékelés és Tervezés Tanszék \\ ${ }^{2}$ Arany János Általános Iskola, Szeged \\ ${ }^{3}$ SZTE JGYPK Alkalmazott Pedagógiai Intézet - Óvodapedagógus-képzö Tanszék \\ ${ }^{4} M T A-S Z T E$ Képességfejlödés Kutatócsoport
}

\begin{abstract}
Absztrakt
A pedagógiai szituációk vizsgálatakor bizonyos esetekben elkerülhetetlen, hogy írásbeli kikérdezéskor nyílt végű tételeket alkalmazzunk. Bár azok sokkal több információt szolgáltathatnak egy adott kutatási problémáról, mint a zártvégủ kérdések, használatuk gyakran háttérbe szorul az adatfeldolgozás nehézsége, összetettsége, idő- és munkaigénye, valamint az ahhoz szükséges szakértelem hiánya miatt. Jelen munkában közölt, általunk készített, Excel-makróval (EKOD) ennek a munkának egy kulcselemét, a kódolást, kategorizálást kívánjuk megkönnyíteni. A tanulmány célja, hogy elemezhetővé tegye az óvodáskorúak IKT-eszközhasználatának feltárására irányuló kutatás meghatározó témakörének, egyik nyílt végű kérdését, a szülők óvodáskorú gyermekeik IKT-használatának hatásáról alkotott véleményét. Munkánkban összefoglaljuk a kódolás metodikai kérdéseit, az adatelemzésben használt megalapozott elméletet, áttekintjük a kvalitatív elemzésre alkalmas szoftvereket. Részletesen bemutatjuk az „IKT eszközök használata óvodáskorban” kérdőív egy nyílt kérdésének elemzésén keresztül az EKOD-ot és annak használatát az adatjelölő kulcskomponensek keresésében, valamint az alapkategóriák felállításában. Munkánk segítheti az óvodapedagógusok kvalitatív vizsgálatait, s ezzel hozzájárulhat különböző jelenségek megértéséhez, illetve az óvodáskorú gyermekek fejlesztéséhez. Ugyanakkor tanulmányunk és az abban közölt program univerzálisan használható más társadalomtudományi kvalitatív kutatásokban.
\end{abstract}

Kulcsszavak: kvalitatív adatok kódolása, megalapozott elmélet, szótáralapú kódolás, Excel makrócsomag, IKT-használat

\section{Bevezetés}

Információs társadalmunkban az információhoz, a tudáshoz való hozzáférés kulcselemei az infokommunikációs technológiák (IKT) (Aldhafeeri \& Palaiologou, 2016; Arnott, 2013; Marsh, Kontovourki, Tafa, \& Salomaa, 2017). Ez a 
tétel nem csak az iskoláskorú vagy felnőttkorú lakosságra vonatkoztatható, hanem az óvodáskorú, illetve annál fiatalabb populációra is érvényes (Holloway, Green, \& Livingstone, 2013). Az IKT mint erőforrás az intézményes nevelés által minél hatékonyabb módon történő kihasználása és felhasználása érdekében számos kutatást kezdeményeztek a technológia fogyasztás és az IKThasználat gyermekek fejlődésére gyakorolt hatásáról. Azonban a téma iránti élénk érdeklődés mellett viszonylag szegényes az óvodai innovációt megalapozó empirikus vizsgálatokból származó információk köre (Couse \& Chen, 2010; Vandewater, Rideout, Wartella, Huang, Lee, \& Shim, 2007). Ezt a hiányt pótolta Hódi, Tóth, B. Németh és Fáyné Dombi (2018) nagymintás, szülők körében végzett kérdőíves vizsgálata. Ennek keretében adatokat gyüjtöttek arról, hogy az óvodáskorú gyermekek milyen IKT-eszközöket használnak, milyen rendszerességgel, mennyi ideig, illetve milyen szülői kontrollal teszik azt. Eredményeik szerint a vizsgált óvodáskorú gyermekek döntő többsége technologizált háztartásban nő fel, és egy részük maga is rendelkezik IKT-eszközzel. Ebben a korosztályban még nem jellemző a napi szintű eszközhasználat, azonban a szülők válaszai rámutattak arra, hogy a fogyasztott tartalmak igen széles skálán mozognak.

A szülők válaszai leképezik az évek óta tartó vitát az eszközök vélt vagy valós, jótékony vagy káros hatásáról, hiszen a vizsgált gyermekek egy része egyáltalán nem használ IKT-eszközt, annak ellenére, hogy azokból legalább egy darab van minden háztartásban. A vizsgálat kérdőíve, céljának megfelelően, módszertani szempontból kvalitatív és kvantitatív kérdőív tételeket is tartalmazott. Az otthoni technológiafogyasztásra vonatkozó mutatók (például otthoni digitális környezet jellemzői, használt eszközök, fogyasztott digitális tartalmak, képernyőidő) publikálásra kerültek (Hódi, Tóth, B. Németh, \& Fáyné Dombi, 2019). Jelen tanulmány célja, hogy bemutassa a szülők percepcióit és preferenciát jelző nyílt végü kérdésekkel gyüjtött adatok feldolgozásán keresztül, a kódolás egyes lépéseit egy saját fejlesztésű, nyílt hozzáférésű Excel-makróval.

Az információkat gyűjtő szakértőknek, pedagógusoknak, pedagógusképzésben résztvevő hallgatóknak gyakran mérési tapasztalatok hiányában nehezen megoldandó technikai feladatot is jelent a betü/string típusú adatok (adatszó, mondat, szöveg) feldolgozása ${ }^{1}$. Tanulmányunkban ehhez szeretnénk segítséget adni, a kutatásunk nyílt kérdéseire kapott válaszok számítógéppel támogatott kódolása során szerzett tapasztalatok bemutatásával. Áttekintjük a kódolás módszertani kérdéseit, a megalapozott elméletet (grounded theory) és a számítógép használatának lehetőségeit a kódolás folyamatában és a kvalitatív adatok elemzésében. Egy konkrét példán keresztül részletesen bemutatunk egy saját fejlesztésű Excel-programot, valamint annak használatát az adatjelölő kulcskomponensek (szavak, kifejezések) keresésében és az alapkategóriák (adatcsoportok) felállításában.

\footnotetext{
${ }^{1}$ A betű vagy stringtípusú adatok, szövegek kódolásának problémája jelen van a napi osztálytermi gyakorlatban is, például témazáró vagy vizsga feladatlapok nyitott kérdéseinek, esszétípusú feladatainak értékelésekor.
} 


\section{Kvalitatív adatok kódolása}

A kvalitatív adatok feldolgozásának első lépése a kódolás. A kódolás az adatok megjelölése olyan címkékkel (kódokkal), amelyek azonosítják, kategorizálják és kvantifikálják azokat (Charmaz, 2006; Szokolszky, 2004). A kód megmutatja az adat helyét a felállított fogalom- és kategóriarendszerben. Az úgynevezett „beszédes” címkék amellett, hogy azonosítják az egyes adatokat, csoportokat/kategóriákat, lehívják azok tartalmát, segítenek felidézni a jelölő fogalom jelentését. A kvantifikálást elősegítendő, gyakran használunk numerikus kódokat, amelyek első karaktere a legáltalánosabb, a legmagasabb absztrakciós szintű fogalmat/kategóriát ${ }^{2}$, az utolsó karaktere pedig az alapszintű adatcsoportot jelzi.

A kódolás lényegét tekintve tulajdonképpen elméletalkotás, elemzések szisztematikus sorozata, amely feltárja a vizsgálat tárgyát leíró fogalmakat és azok kapcsolatrendszerét, a vizsgált jelenséget magyarázó elméletet. Technikailag a kódolás adatredukció (Szokolszky, 2004. p. 240), adatösszevonás és kategorizálás, az adatok jelentésalapú csoportosítása és egyre általánosabb, absztraktabb fogalmak alá sorolása. (1. ábra)

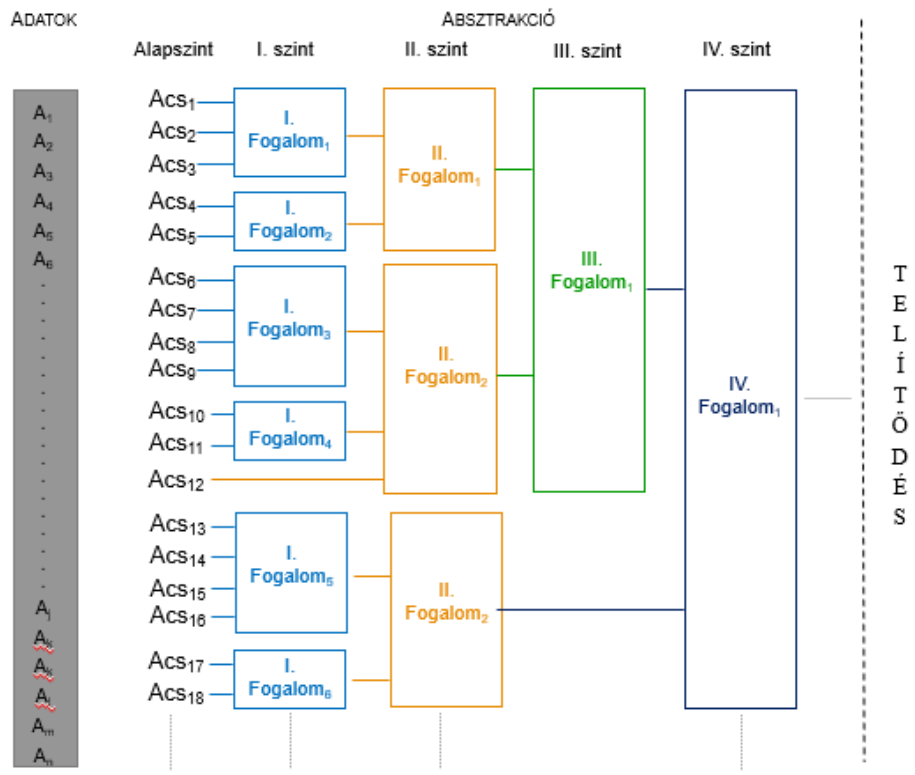

1. ábra

Kvalitativ adatfeldolgozás - elméletalkotás egy lehetséges fogalomstruktúra részlete (Forrás:saját szerkesztés, Charmaz, 2006 alapján)

${ }^{2}$ A „fogalom” kódolás elméleti, a „kategória” kódolásmódszertani, technikai kifejezés. 
A kódolás az adatkorpusz (adattömb) előállításával, az adatok rögzítésével kezdődik, amelyet a közös jellemzők, kulcskomponensek, az indikátorok, integráló fogalmak keresése követ az adattípusra (például string, audio, képi, videó) jellemző komponensek, adatszegmensek (például adatszavak, adatsorok, képelemek, eseményrészletek) leíró vizsgálatával. A stringtípusú adatok esetében például szógyakoriság vizsgálat, kulcsszavak, kulcskifejezések keresése, listázása és jelentésalapú értelmezése. Az elemzés minden adathoz egy-egy integráló fogalmat/kulcskomponenst kapcsol, amelyek mentén azok összevonhatók, az alap fogalmi kategóriák (core conceptual categories), adatcsoportok képezhetők. Az adatredukció következő szakasza a fókuszelemzés, a fogalmak, csoportok integrálása, az adatok, csoportok és kategóriák összevonása tartalmuk elvesztése nélkül. (2. ábra) ${ }^{4} \mathrm{Az}$ adatösszevonás során képzett egységeket a kódolás elméleti kontextusában fogalmaknak (1. ábra), a kódolás technikai terminológiájában kezdő szinten csoportoknak, felsőbb szinteken kategóriáknak nevezzük (Charmaz, 2006; Corbin \& Strauss, 1990; Szokolszky, 2004). (2. ábra)

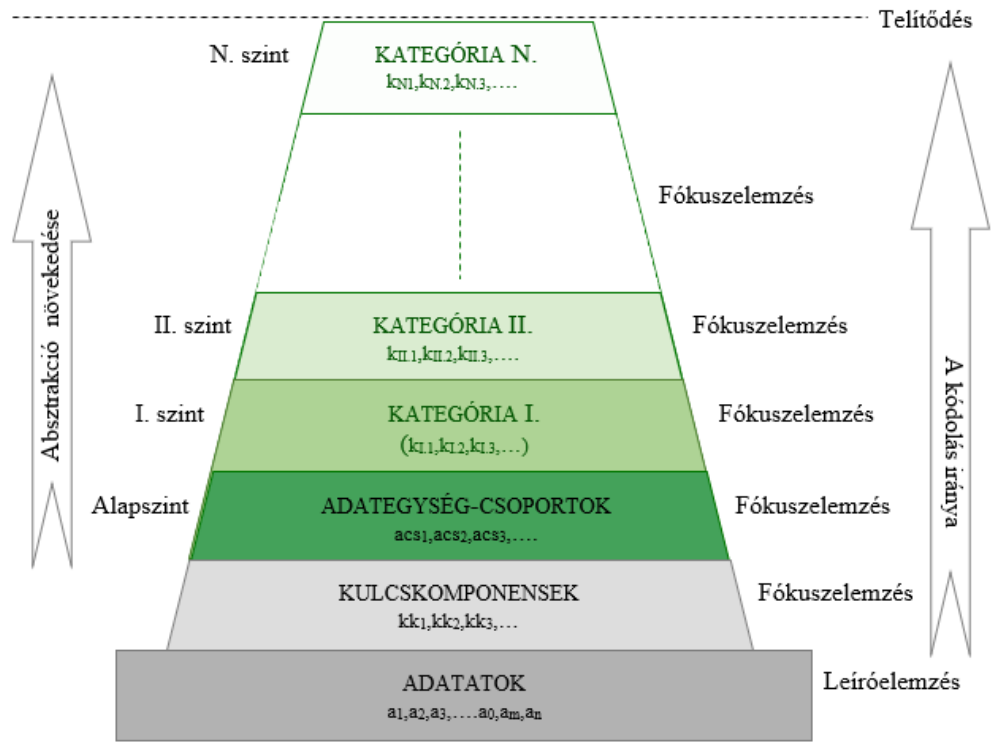

2. ábra

Kvalitatív adatok kódolásának technikai lépései (Forrás: saját szerkesztés).

${ }^{3}$ A corpus latin szó, jelentése test. A nyelvészetben adott időpontban használt, számítógépen tárolt, számítógéppel feldolgozható szövegek összessége. A kvalitatív kutatásokban az adatkorpusz az elemzés tárgyát képező különböző típusú (például string/betű, audio/hang, képi, videó) adattömböt jelent.

${ }^{4}$ A fókuszelemzés kifejezést Charmaztól (2006) vettük át. 
A fókusz-, vagy más kifejezéssel, integráló elemzés többirányú és több szintet érintő műveletsor, az indikátorkeresést követő adat-, illetve kategóriaösszevonások sorozata. A fókuszelemzés adatokat adatokkal, adatokat kódokkal (például kulcskomponensekkel, csoportokkal, kategóriákkal), valamint csoportokat csoportokkal, csoportokat kategóriákkal és kategóriákat kategóriákkal hasonlít össze és rendez (másféle) csoportokba, majd kategóriákba. Az adatcsoportok, illetve -kategóriák összevonása az elemzés -> hipotézisalkotás -> ellenőrzés lépések sorozata a telítődésig (elméleti saturációig), mindaddig, amíg további összevonást már nem tudunk tenni, újabb kategóriákat már nem tudunk felállítani (Charmaz, 2006; Holton, 2010).

Az adatcsoportoknak és -kategóriáknak diszjunkt halmazoknak kell lenniük, nem lehet közöttük tartalmi átfedés (Szokolszky, 2004). A szintek és kategóriák számának emelésével növekszik a vizsgált jelenség leírásának részletezettsége, pontossága, ugyanakkor csökken a rendszer kezelhetősége. Kevesebb szint és kategória alkalmazása javítja az áttekinthetőséget, de egyúttal a kódolás pontosságát, érvényességét érintő információvesztéssel jár. Az optimális tagolás a lényegesnek, jelentősnek ítélt különbségek megjelenítéséig tart. Fontos kritérium, hogy a kategóriák és logikai kapcsolataik összhangban legyenek a kutatási kérdéssel (Szokolszky, 2004). Az adatok elemzése gyakran több megoldást kínál, különösen a nyílt kódolás eseten (lásd Adatok kódolása fejezet).

A kódolás lehet deduktív és induktív, illetve a kettő kombinációja. Deduktív, ha korábbi kutatások tapasztalatait követi, „kész” elmélet alapján valósul meg, másképpen, ha az aktuális adatokban mások által kidolgozott eljárást követve, már felállított csoportokat/kategóriákat keres. Induktív módszerről beszélünk, amikor a kódolás során figyelmen kívül hagyjuk a releváns szakirodalmat, és kizárólag az adatokban rejlő összefüggések feltárására törekszünk, az adatok csoportképző kulcskomponenseinek azonosítását követő általánosabb kategóriákra érvényes következtetéseket fogalmazunk meg. A kódolás során a kategóriaképzés szempontjai folyamatosan módosulhatnak, különösen az induktív módszer esetében. Ezért azokat rögzítendő, az elemzések során emlékeztetőket úgynevezett memókat, különböző szempontok szerint (például módszertani, terminológiai) rendezett feljegyzéseket készítünk. Azok alapján értelmezhető a kódolás eredménye, a kód, illetve visszakövethető a kódolás folyamata, módosítható annak iránya, finomíthatók a kategóriák, felfedhetők a kapcsolatok (Charmaz, 2003; javaslatokat a memók íráshoz lásd Charmaz, 2006, p. 72-95; Sánta, 2013).

Mint az eddigiekből látható, a kódolásból nem zárhatók ki a szubjektív döntések, viszont kiemelten fontos, hogy az objektivitás biztosítása mindenkor figyelmet kapjon. A kódolás eredményessége részben a kódoló intuícióinak, tudásának, tapasztalatainak függvénye. Vagyis ugyanahhoz az adathoz különböző személyek más-más kódokat rendelhetnek (Giorgetti, \& Sebastiani, 2003), eltérő kapcsolatokat azonosíthatnak. Ezért is lehet érdemes átgondolni a kutatásban résztvevő kódolók számát. 


\section{Módszertani keretrendszer: grounded theory (GT-módszer)}

A grounded theory (Glaser \& Strauss, 1967), tükörfordításban megalapozott elmélet ( Gelencsér, 2003; Mitev, 2012; Corbin \& Strauss, 2015) ${ }^{5}$ a kvalitatív elméletalkotás egyik leggyakrabban használt módszertani keretrendszere (Mitev, 2012), „rendszerezett, konzisztens empirikus-módszertani eljárásgyűjtemény" (Kucsera, 2008. p. 99). Alaptétele szerint az elméletépítés empirikus adatokból nem előre megfogalmazott hipotézisek mentén történik. Az elmélet a kódolás vonatkozásában a vizsgált jelenség érvényes, absztrakt, fogalmi magyarázatát adó, empirikus adatokból feltárt fogalmak, fogalomcsoportok kapcsolata. (1. ábra)

A GT-módszer lényege a fogalomspecifikáció (Staruss, 1987). Analitikus indukció, amelyben az elemző fogalomindikátor modell (concept-indicator model) mentén szisztematikus kódolási műveletek, stratégiák sorozatával azonosítja az adatok tartalmi, jelentésbeli lényegét kifejező kategóriákat. Többirányú és folyamatos összehasonlító módszerrel (constant comparative method) feltárja az adatredukciót megvalósító, kategorizálást szervező indikátorokat, az adategységek (például interjúalanyok válaszainak), illetve a képzett kategóriák azon tartalmi, jelentésbeli elemeit, amelyek ugyanabba a kategóriába tartozást, ugyanazt a fogalmat jelölik (Dömsödi, 2003; Kucsera, 2008; Mitev, 2012; Staruss, 1987). A kódolás adatgyüjtés-elemzés-elméletalkotás ciklusokkal valósul meg, melyek az elmélet telítődéséig (theoretical saturation) ismétlődnek, amíg újabb adatok már nem bővítik, újabb információk már nem gazdagítják az elméletet ( Dömsödi, 2003. p. 21; Gelencsér, 2003; Mitev, 2012).

A grounded theory megjelenése óta (Glaser \& Strauss 1967) számos olyan GT-változat jelent meg (Gelencsér, 2003; Kucsera, 2008; Mitev, 2012), melyek a tudományfilozófiai megközelítésen túl, alapvetően az alkalmazás rugalmasságában különböznek és eltérően vélekednek a korábbi tudományos tapasztalatok szerepéről, elméletalkotásba való bevonásáról (Sallay, 2015). Például a módszer történetének későbbi szakaszában a szerzőpáros két tagja is eltérő nézetet képvisel. Glaser $(1978,1992,2004)$ a GT-t felfedezési módszernek tekinti és a szigorúan induktív kódolási módszer mellett foglal állást. Strauss és Corbin (1998) a deduktív elemek használatát is elfogadhatónak tartják, az érvényességet és a verifikációt hangsúlyozzák (Corbin \& Strauss, 1990, 1998, 2015; Strauss 1987; Strauss \& Corbin, 1990, 1998; Gelencsér, 2003; Kucsera, 2008; Mitev, 2012). Charmaz (2003) mindkét felfogást merevnek ítéli, rugalmasabb konstruktivista álláspontot képvisel. Szerinte a

\footnotetext{
${ }^{5}$ A grounded theory fordításai még a „lehorgonyzott elmélet» (Bodor, 2013; Rácz, 2006), „alapozott elmélet" (Kucsera, 2008; Szokolszky, 2004; Vicsek, 2006), Ehmann (2002) és Seidman (2002) munkáinak fordítói megtartották az eredeti angol kifejezést. Tanulmányunk Corbin és Strauss „A kvalitatív kutatás alapjai” című könyvének terminológiát használja (Sallay, 2015), a GT-módszer kifejezést a konkrét módszerek, módszertani keret megjelölésére és a megalapozott elméletet a GT-módszer eredményének kifejezésére használja. A grounded theory kifejezésben a „theory” (elmélet) módszertani eljárásokat jelöl.
} 
módszer csak iránymutatás, amellyel a kutató a kategóriákat, kódokat nem felfedezi (mint a klasszikus megalapozott elméletben), hanem konstruálja. A kutatások GT-módszerek széles skáláját használják a kutató felfogásától és a kutatás paramétereitől (például cél, kontextus) függően. Az alkalmazások egy részében csak eszköz az adatfeldolgozásban, és nem történik eleméletalkotás (Sallay, 20015).

\section{IKT-alkalmazások a kódolásban}

A megalapozott elméletnek köszönhetően „kibontakozott a kvalitatív módszerek reneszánsza" (Kucsera, 2008. p. 99), a számítógép bevonása a vizsgálatokba forradalmasította a kvalitatív adatelemzést (Dömsödi, 2014; Szokolszky, 2004). A számítógép bevonása a kvalitatív kutatásba növelte az adatfeldolgozás pontosságát és megbízhatóságát, lerövidítette annak időtartamát, követhetőbbé, áttekinthetőbbé tette a kódolás folyamatát.

A technológiával támogatott kvalitatív adatfeldolgozásban jelenleg két eljárás honos, a számítógéppel segített és az automatizált kódolás. A számítógéppel segített kódolást (computer assisted coding - CAC) a kódoló személy és a számítógép együtt végzi. A kódolóprogram feladata, hogy a lehető legtöbb technikai segítséget adja a számítógépen dolgozó, de kézzel kódoló személynek (Macchia \& Murgia, 2002). A program azonosítja, listázza a lehetséges kódokat, a besorolás számba jöhető indikátorait (kulcskomponenseket, kulcsszavakat, kulcskifejezéseket), ajánlásokat tesz az illeszkedő kóddal kapcsolatban, a végeredmény azonban a felhasználó döntése.

A másik eljárás az automatizált kódolás (automated coding - AUC), amely során a számítógép jut központi szerephez, emberi beavatkozás nélkül. Maga a kódolás automatikusan, egy algoritmus segítségével történik, a cél az adategységekhez rendelt kódok számának maximalizálása. A futtatás előtt azonban lehet, hogy fel kell készíteni a programot a válaszok fogadására, s különböző beállításokat kell elvégezni. Mivel a program csak előzetesen megadott keresőkifejezéseket vizsgál, lehetnek olyan adategységek, melyek nem kapnak kódot, ezekben az esetekben azt „kézzel” kell elvégezni (Macchia \& Murgia, 2002).

Számítógéppel segített feldolgozást támogató modullal rendelkezik például a Statistics Netherlands által több mint 30 éve fejlesztett Blaise program. A kódoláshoz előzetesen egy, a kódokat tartalmazó úgynevezett szótárt kell készíteni és betölteni. Annak alapján a program kódfát generál, majd kódolási módot kínál, lépésenkénti és a szótárkódolások, valamint a kettő kombinációja közül választhatunk (részletesen lásd Macchia, \& Murgia, 2002).

A szövegek manuálisnál hatékonyabb feldolgozására fejlesztett automatikus kódolási módszer Automatic Coding by Text Recognition (ACTR). Az algoritmus működéséhez szükség van egy kódszámokat és kulcskifejezéseket tartalmazó kódbázisra. A program először a kódbázissal konzisztens standard formátumúvá alakítja az adatokat (ez megtörténik akkor is, ha új elemet 
veszünk fel a kódbázisba), majd megvizsgálja a szórendet. Felismeri például a hiányzó vagy duplikált szavakat, helyesírási vagy gépelési hibákat, rövidítéseket, többes számot, szinonimákat. A következő lépésben az átalakított adatokhoz illeszti a kódbázisban található kulcskifejezéseket. Ha a kulcskifejezés összes szava illeszkedik a válaszra, akkor teljes egyezésről beszélünk. Részleges egyezés esetén, azaz, ha legalább egy szó illeszkedik, az algoritmus gyakoriság alapján súlyozza a lehetséges találatok szavait és a súlyok összegét, mint pontszámot, hozzárendeli a találathoz. A legtöbb pontot érő találat kapja meg a kódot (Rowe \& Wong, 1994).

Az automatizált kódolási mechanizmusok két eljárást alkalmaznak. Az egyik a már említett szótáron alapuló, a másik gépi tanulást megvalósító algoritmusokat használ. A szótáralapú kódolási eljárások lényege, hogy kódszámokhoz szavak együttese tartozik, és a kódot a szótár elemei közötti kapcsolat határozza meg. Vannak programok, melyek a kódkiosztásban a szavak közötti logikai kapcsolatokat is figyelembe veszik (lásd Viechnicki, 1998). Viechnicki módszerénél szignifikánsan hatékonyabbnak bizonyult a kódolást szövegkategorizáló problémaként megközelítő tanuló algoritmusokkal müködő program (Giorgetti \& Sebastiani, 2003). Lényege, hogy egy algoritmus adott számú adat manuális kódolásának mintázata alapján hozza létre azt a kódbázist, amely alapján kódolni fogja a többi választ (például WordStat a Provalis Research programja). A tanuló algoritmussal való kódolás sosem lehet annyira pontos, hogy nélkülözze a kézi ellenőrzést, de jelentősen csökkenti a magas szintü pontosság eléréséhez szükséges emberi közreműködést.

A pontosság növelése azonban a teljes automatizálás kárára történhet. Schonlau és Couper (2016) félautomata kategorizáló programjával közel $80 \%$-os pontosság érhető el. Schonlau és Couper is a válaszok egy részét (500 választ) kézzel kategorizálták, majd egy statisztikus tanulóalgoritmust használtak. A program esetenként túlbecsülte a leggyakoribb kategóriát, az összetett, zavaros válaszokat sokszor a legnagyobb gyakoriságú kategóriába sorolta, ami torzította az eloszlást (Schonlau \& Couper, 2016). Ezért egy szerü, illetve kevés adat esetén inkább a kézzel kódolást javasolják, nagy feldolgozandó adatmennyiség, komplex adatok esetében azonban mindenképp jónak látják a számítógép bevonását.

A számítógéppel támogatott kvalitatív adatelemzés (Computer Assisted Qualitative Data Analysis Software - CAQDAS) megjelenése óta hosszú utat tett meg a lyukkártyás számítógépek használatától az elméletépítésre képes szoftverekig (Ehmann, 2002). A ma elérhető alkalmazásoknak három típusát különböztetik meg, a 1. szövegkereső, 2. a kódoló-kereső és 3. az elméletépítő szoftvereket (Ehmann, 2002; Sánta, 2009; Szokolszky, 2004).

A programok mindegyike elvégezi a szógyakoriság-elemzést, és az adatok megadott kódszavak szerinti kódolását, szegmentálását. A szövegkereső programok (például Word Perfect, jelen tanulmányban bemutatott Excelmakro) a megadott kódszavak alapján kódokat rendelnek az adatokhoz és el- 
különítik, külön fájlokba rakják az azonos kódokhoz tartozókat. Van köztük olyan is, amellyel tartalomelemzés is végezhetö, számbaveszi a megadott szavak, illetve azok kombinációinak előfordulását. A kódoló-kereső szoftverek (például Ethnograph) tagolják a szövegeket, kódolják a képzett szegmenseket és megjelenítik azokat. Némelyikük memok, kódolási jegyzetek írását támogatja. Az elméletépitő programcsomagok jellemzően a megalapozott elmélet (Glasser \& Strauss, 1967) alapelvei mentén müködnek. A kategorizáláson túl, a kapcsolatok elemzésére is alkalmasak, támogatják a fogalmi integrációt és a képzett struktúrák, az elméletépítés hipotéziseinek, ellenőrzését (Szokolszky, 2004). E csoportba tartozik a három legnépszerübb programcsomag az NVivo, az ATLAS.ti, és a MAXQDA. Az Nvivo és az ATLAS.ti használható szöveges dokumentumok, képek, videók és hang fájlok elemzésére. Az Nvivo kvalitatív és vegyes módszertani kutatásokban preferált, képes a közösségi média, a Facebook, a Twitter és a LinkedIn adatainak rögzítésére, oneNote, Excel, SPSS-kompatibilis adatfájlokat szolgáltat. Az ATLAS.ti alapvetően asztali alkalmazás, de bétaverzióban már elérhető az ATLAS.ti CLOUD webalkalmazásuk is. Az ATLAS.ti-ben ábrázolhatók a kódok, a Networkfunkció segítségével fogalmi, gondolati térképek rajzolhatók, megnézhető és alakítható a fastruktúra (Dömsödy, 2014). A MAXQDA-val kódolhatók a hagyományos dokumentumtípusok mellett az internetes kérdőívek válaszai, feldolgozhatók a Twitter-bejegyzések és YouTube kommentek is. MAXQDA-ban kódok aktiválhatók, illetve deaktiválhatók, az adatok egyszerre több kódot is kaphatnak. A kedvencek lista a gyakran használt kódok tárolásával gyorsítja a kódolás folyamatát. A CreativeCoding funkció segítségével átláthatóbbá tehető a kódolás és beállíthatók az alá-fölérendelt-ségi viszonyok. A kódolt adatokhoz megjegyzések füzhetők, melyek Excel-munkafüzetbe vagy HTML-formátumba exportálhatók. A programban számos beépített lekérdezésre, statisztika előállítására is van lehetőség.

Dömsödi (2014) szerint a kvalitatív adatkezelő programoknak van egy negyedik, beépített statisztikai funkciókkal felszerelt csoportja is. Ilyen például a klaszteranalízist is kínáló QDA (Dömsödy, 2014), vagy a komolyabb statisztikai elemzésekre is alkalmas automatizált kódolást végző WordStat a Provalis Research tartalomelemző és szövegbányászati szoftvere (Macer, 2008). A szöveg, hang és kép kódolására fejlesztett Dedoose programmal szintén futtathatók statisztikai becslések, próbák és szerkeszthető diagramok.

\section{Az „IKT-eszközök használata óvodáskorban” kérdőív kvalitatív adatainak feldolgozása}

A kutatók az adatfeldolgozás módszertani nehézségei, továbbá annak időigényessége és magas költségvonzata miatt lehetőség szerint nem használnak nyílt kérdéseket (Geer, 1991; Schonlau \& Couper, 2016). Azok alkalmazása azonban megkerülhetetlen, ha nem ismerjük a lehetséges, a várható válaszokat. Ez történt az „IKT-eszközök használata óvodáskorban” kutatás esetében 
is. 2017- ben, a vizsgálat időpontjában ugyanis még nem voltak nagymintás hazai adatok és nemzetközi viszonylatban is kevés információ állt rendelkezésre a hat évnél fiatalabb gyermekek technológia fogyasztásáról, digitális média környezetéről. Ezért nyílt kérdésekkel vizsgáltuk a szülők gyermekük otthoni, illetve óvodai IKT-használatával kapcsolatos nézeteit. Egy nagyváros önkormányzati fenntartású óvodáiban végzett papíralapú adatfelvétel az összes kitöltés 51,0-80,5\%-ában hozott szöveges választ, és 960-1550 írásban kifejtett vélemény, álláspont kódolását kellett elvégezni. (Az alkalmazott módszereket és eszközöket lásd Hódi, Tóth, B. Németh, \& Fáyiné Dombi, 2019.)

A kvalitatív adatfeldolgozás az elméleti keret (framework) kiválasztásával kezdődik. Ehhez szükség van a kutatási kérdés módszertani értelmezésének megfogalmazására, arra, hogy hogyan, milyen formában kívánjuk megvalósítani a kutatás célját. Az „IKT-eszközök használata óvodáskorban” projekt esetében ez a következőt jelentette. A vizsgálat egyik célja a szülők gyermekük otthoni, illetve óvodai IKT-használatára irányuló preferenciáinak és percepcióinak feltérképezése volt. Arra voltunk kíváncsiak, hogy mit „mondanak” a kapott válaszok. Annak feltárása pedig nyílt kódolással, és amennyire csak lehetséges, a szakirodalomtól, a gyermeknevelésben érintett szakemberek (pedagógusok, orvosok, pszichológusok, tanácsadók) véleményétől független induktív elméletalkotással valósítható meg. Ehhez a támogató módszertani útmutatást GT-módszerben találtuk meg, melynek alapja a nyílt kódolás és az adatok jelentésének absztrakciójával adatokból felépített elmélet (fogalmak és kapcsolataik felfedése). De jellemző még rá a módszertani rugalmasság, párhuzamos elemzés és elméletalkotás; reflexiók folyamatos rögzítése, reflektív szakirodalomhasználat (Charmaz, 2006; Kucsera, 2008; Sallay, 2015), amelyeket szintén fontosnak ítéltünk. Az alkalmazott kódolási stratégia a különböző GT-értelmezések közül leginkább a Charmaz (2003) képviselte „mit” és „hogyan” kérdésekre fókuszáló konstruktivista megközelítéshez áll közel (Sallay, 2015).

A kvalitatív adatfeldolgozás következő szakasza a kódolás technikai tervezése. Az, hogy milyen, a frameworköt leginkább kiszolgáló és a tudományosság kritériumainak biztosítását segítő eszköz(öke)t és konkrét elemzési stratégiát, módszert alkalmazunk, függ a feldolgozandó adatkorpusz paramétereitől, terjedelmétől (mennyiségétől) és típusától (például string, kép), illetve annak meghatározó jegyeitől (például stringtípusú adat esetében függ attól, hogy az mondat vagy hosszabb szöveg, és milyen aktuális sajátosságai vannak, így akár a szavak száma vagy a mondatszerkezet). Az „IKTeszközök használata óvodáskorban" kutatásban a szülők jellemzően egy, ritkábban két-három egyszerü, időnként bővített mondatban fogalmazták meg válaszaikat, amelyek soha nem voltak összefüggő szövegek. A vizsgálatban kapott közel 1000-1550 stringtípusú válasz feldolgozását kellett elvégezni. Ekkora terjedelmű adatkorpusz kézi kódolása már érvényességi és megbízhatósági aggályokat vet fel, ezért szoftveres támogatást kerestünk. A különböző megoldásokat kínáló kvalitatív kódolásra alkalmas, a GT-módszer 
kritériumainak is megfelelő kereskedelmi szoftverek (például Word Perfect, MAXQDA) helyett azonban saját Excel programban készített makrócsomagot $^{6}$ készítettünk, amit EKOD-nak neveztünk el. Miután körvonalazódott, hogy mit, milyen elemzéseket, a kódolás mely feladatait szeretnénk gépi kódolással végezni, arra a következtetésre jutottunk, hogy azok az Microsoft Excel programban is megvalósíthatók. Excel-makróval is futtatható szógyakoriság-vizsgálat, azonosíthatók a csoportképző indikátorok és tömbösíthetők az adategységek. Excelben is használhatók összetettebb kereső kifejezések (logikai műveletekkel összekapcsolt szavak), valamint egy válaszhoz több kód is rendelhetö, vagyis összetett válaszok is kódolhatók.

Kutatásunkban kiemelten fontos szempont volt az idő. Az induktív kódolás/kategorizálás elemzések, hipotézisek és azok ellenőrzésének ciklusaiból áll, amely technikailag az adategységek többszöri újrarendezését és az adatcsoportok ismételt kontrollját jelenti. Vagyis a szoftver beállításain a kódolás során gyakran kell változtatni. Az egyszerü, könnyen elsajátítható programok használatával időt spórolhatunk. Ilyen a Microsoft Excel program, amelyet szinte mindenki ismer, aki Microsoft Office programcsomagot használ. Az Excel-program felhasználóbarát, az adatait az alapértelmezett ,xlsx', illetve 'xls' és a ,csv' formátumokat több statisztikai szoftver is beolvassa (például SPSS), de könnyen exportálhatók más formátumokba is.

Az Excel használata mellett szólt még, hogy elérhető külön költségvonzat nélkül is. Az említett kereskedelmi programok demoverzióival szemben nincs idő-, és a vizsgált adat mennyiségére-, a kódok számára vonatkozó korlát, illetve adatbetöltési problémával sem kell megküzdeni (az adatkorpusz Excelben készült). Például a mindhárom platformmal (Windows, Linux, Mac) kompatibilis Quirkos program húsznapos ingyenes próbaverziója nem működött tökéletesen a ,csv' formátumú adatfájllal (nem mindenhol ismerte fel a pontosvesszőket), holott a leírás szerint képes annak beolvasására. Az általunk készített EKOD-ot az „IKT-eszközök használata óvodáskorban” projekt kvalitatív adatainak feldolgozása során a kódszótár készítéshez, adategységek kódolásához használtuk.

\section{Az adatkorpusz elöállitása és jellemzői}

Mint minden más esetben, az EKOD is vele kompatibilis formátumú adatokon futtatható. Az adatfeldolgozás első lépése az adatkorpusz előállítása volt. A válaszok rögzítése ,xlsx' kiterjesztésű Excel-fájlban történt, kérdésenként másmás munkalapokon. İgy a kódolást az adatokat tartalmazó állományban végezhettük, külön program telepítése nélkül ${ }^{7}$. Az adattáblában egy sor egy kitöltés

\footnotetext{
${ }^{6}$ A makró egy a Microsoft Excel saját formátumához tartozó, VB- nyelven írt program.

${ }^{7}$ A számítógépes környezetben felvett kérdőívek adatait szintén Excel-táblázatban szokták exportálni. A legtöbb ingyenes kódoló alkalmazásával azonban nehézkes a Excel-táblázatok adatainak feldolgozása.
} 
adatait tartalmazza, nevezetesen az azonosítókat, sorszámot8 és az interjúalany válaszát, annak adategységeit. A sorszám szükséges a kvantifikáláshoz, a kérdőív kvalitatív és kvantitatív adatainak összefüzéséhez. Jelen kutatásban az adategység egy írásban kifejtett gondolat, egy állítás, amely formailag lehet egy vagy több mondat, illetve mondatrész. A vizsgálatban a szülők egy, néha két és ritkán három mondatban fogalmazták meg álláspontjukat a feltett kérdésekre. A hoszszabb, több gondolatot tartalmazó válaszok jellemzően független állítások, nem tekinthetők összefüggő szövegnek. Az adategységek hossza változó, vannak kéthárom szóban megfogalmazott (például „Függővé válik.” „Később hasznos lesz.”) és hosszabb vélemények is (például „A fejlődésben lévő szemüknek nem tesz jót, ha sokat használják és csak közelre fókuszálnak.").

Ugyanannak a kitöltésnek az adategységeit ugyanabban a sorban, de külön cellákba (adatmezőkbe) rögzítettük. A készített makró akkor is müködik, ha az adategységeket nem szeparáljuk. Külön cellákban való megjelenítésük azonban megkönnyíti a kontrollt, egyszerüsíti a gépi kódolásból egyezés hiánya miatt kimaradó adategységek kézi kódolását.

\section{Kódszótár készítése}

A kódolás a „munkafájl” létrehozásával kezdődik. A „nyers” (az adatokat az eredeti, rögzített formájukban tartalmazó) adattábláról másolatot készítünk és a kódolást abban végezzük. Ennek egyik munkalapján a rögzített adategységek vannak. Az első sorban találhatók az azonosító információk: a kérdés, amelynek válaszait a munkalap tartalmazza, az adott oszlopokban levő adatokat megnevező oszlopfejlécek. ${ }^{9}$ Egy oszlopban ugyanannak a változónak az értékei vannak (például intézménynév, az interjúalany azonosítói, sorszám, illetve az intézmény és az óvodai csoport neve és kódja), majd az adategységek oszlopai következnek. Az adattáblában az összes kitöltés szerepel, ezért készítettünk egy jelzőoszlopot, amely megmutatja, hogy az adott kitöltés tartalmaz-e kvalitatív adatot (válaszolt-e az interjúalany a kérdésre). Így egyszerűen leválaszthatók az „üres” sorok és ellenőrizhető, hogy kapott-e kódot minden adategység. A kódolás során a makró az elemzések eredményeit lépésenként más-más munkalapra rakja. Így a folyamat jól követhető, és a tartalmi kontrolállás gyorsabban elvégezhető.

A kódszótár készítése két szakaszból áll: kulcsszavak kiválasztásából (1) és kódlista felállításából (2). Az ezekhez használt programok külön-külön futtathatók.

\footnotetext{
${ }^{8}$ A jól felépített sorszámból kivághatók a minta jellemző paraméterei (esetünkben például intézmények, óvodai csoportok), azok a mutatók, amelyekkel a statisztikai elemzések során részminták képezhetők. Fontos, hogy tömbösítéskor, az adattömbök átrendezésekor a sorszámok együtt mozogjanak az adategységgel.

${ }^{9}$ Egy oszlopban ugyanannak a változónak az értékei vannak például sorszám, az intézmény és az óvodai csoport
} 


\section{A kulcsszavak kiválasztásához}

A kulcsszavak kiválasztásához először szógyakoriság-vizsgálatot végzünk. Jelen kutatásban a ,vizsgalSzogyakorisag' makrót futtattuk a válaszok adategységeit tartalmazó 'valaszok' munkalapon. A makró megvizsgálta, hogy az adategységeket alkotó szavak hányszor fordulnak elő az adattáblában, és listázta az eredményt a 'szavakgyakorisága' nevü munkalapon gyakoriság szerint csökkenő sorrendben. A ,vizsgalSzogyakorisag' makró részegyezéseket is vizsgál, szemben az ingyenesen elérhető szógyakoriságot vizsgáló szoftverekkel. Például a „függőség, ,függővé válik” és „függő lesz” kifejezéseket azonosnak tekinti, és azok találatainak összegét írja ki a gyakorisági táblázatba.

A következő lépés a szürés, a kutatási kérdés szempontjából relevánsnak tűnő szavak kiemelése. A kiválasztás annak eldöntése, hogy egy-egy szó bírhat-e érdemi, valós jelentéssel az adott kérdés megválaszolásában, vagy csak a fogalmazás, a mondatfüzés eszköze. Például "van", "is", és, "neki", "egyedül", "nem” szavak esetében. A „tünő" szó arra utal, hogy ennek megítélésében nyílt kódolás esetében (mint jelen kutatásban is) csak az adott kérdés nyelvi értelmezésére támaszkodhatunk.

A kulcsszavak kiválasztásához az egyik támpont a gyakoriság. A kódlistába elsőszőr a leggyakoribb jelentéssel bíró szavak kerülnek. Könnyen adatvesztéshez vezethet, amennyiben tartalmi kontroll nélkül csak az alapján dolgozunk. Lehetnek ugyanis a téma szempontjából lényeges tartalommal bíró, kis gyakoriságú adategységek. Ez történt az IKT-használat pozitív hatásaira vonatkozó kérdés válaszainak feldolgozásakor is. A kódokhoz generált munkalapok, illetve a kód nélkül maradt adategységek átnézésekor ugyanis találhatunk ilyen, a kiinduló hipotézisből is hiányzó tartalmakat. Ilyen volt például a „kor”, „korunk” szavak. A kódok szerint szegmentált adategységek jelentésének vizsgálatkor derült ki, hogy a szülők egy részének az álláspontja a kérdés kapcsán, hogy „Korunkhoz tartozik, hogy a gyermek megismerkedik a használatával." Ez és a hasonló vélemények valójában csak közvetett válaszok a kérdésre. Ilyenek voltak még a „támogat”, szükséges” szavak. A szülők egy része az eszközhasználat pozitív hatásairól alkotott véleménye helyett az eszközhasználathoz való viszonyát, a preferenciáit fogalmazta meg.

\section{Kódlista készitése}

Szótáralapú kódolási eljárásunk következő lépése a kódlistát tartalmazó 'kodok' munkalap elkészítése volt. Az ,A' oszlopba kétjegyü kódszámokat, a ,B' oszlopba pedig a gyakran előforduló szavak közül azokat vettük fel, amelyek megítélésünk szerint utalnak a válasz tartalmára, azaz amelyek kulcsszavak is lehetnek. A pontosság növelésének érdekében a kiválasztott szavak szótöveit használtuk, azok lettek a kódszavak. ( 3. ábra) Érdemes ugyanis egyesíteni, és a továbbiakban egyként kezelni azokat a szavakat, amelyek ugyanannak a szónak képzett, ragozott alakjai (a szógyakoriság elemzés egyes esetekben ugyanis megkülönbözteti, külön tételként írja ki azokat). Ilyenek például a 
játék - játszik - játszani, agresszió - agresszív, von - elvon szópárok. Mivel kód az azonos tartalmú adategységek megjelölésére hivatott, és a további oszlopokban szinonimákat is megadtunk, például lát - néz, mozog - nem mozog - lustul.

\begin{tabular}{|c|c|c|c|c|c|}
\hline 4 & A & B & $\mathrm{C}$ & D & E \\
\hline 1 & 11 & függő & & & \\
\hline 2 & 13 & játék & játszik & játszani & \\
\hline 3 & 14 & szem & & & \\
\hline 4 & 16 & agresszió & agressziv & & \\
\hline 5 & 20 & tartalmak & tartalom & & \\
\hline 6 & 21 & mozgás & nem mozog & lustul & \\
\hline 7 & 25 & kép & & & \\
\hline 8 & 26 & káros & & & \\
\hline 9 & 28 & használja & használata & & \\
\hline 10 & 29 & idő & időt & & \\
\hline 11 & 30 & von & elvon & & \\
\hline 12 & 33 & kevesebb & & & \\
\hline 13 & 34 & gyermek & gyerek & gyerekek & \\
\hline 14 & 35 & tud & tudás & & \\
\hline 15 & 36 & fejlödés & & & \\
\hline 16 & 38 & néz & lát & & \\
\hline 17 & 39 & aktivitás & & & \\
\hline 4 & - & valaszok & orisaga & _statisztika & függőség \\
\hline
\end{tabular}

3. ábra

Az „Ön szerint milyen negatív hatása lehet az IKT-eszközök használatának óvodás korban?" kérdés kódolásához készitett 'kodok' munkalap első 17 rekordja.

\section{Adategységek kódolása}

Az adategységek kódolása, mint minden lépés esetében a ,valaszok' munkalapon állva a 'valaszokKodolasa' makró futtatásával történik. A program lefutása után a 'valaszok' munkalapon az adategységek mellett folytatólagosan megjelenik a talált kód száma és a hozzá tartozó kulcsszó, továbbá egy úgynevezett kódjelölő. Ez 0 vagy 1 attól függően, hogy a makró talált-e kódot az adategységben. A kódjelölő segítségével kiszűrhetők a kód nélkül maradt adategységek. Azokat kézzel kell kódolni. A kódolás törölhető a «torolElozoFutas' makró futtatásával.

A makró készít egy 'statisztika' munkalapot, amely megmutatja a kódok gyakoriságát. Az IKT-használat negatív hatásaira vonatkozó kérdés esetében például 145 adategység nem kapott kódot, a módosított kódlista kismértékű gyakoriságnövekedést hozott.

A ,valaszokKodolasa' makró a kódok adategységekhez illesztésével párhuzamosan minden megtalált kódszóhoz (kulcsszóhoz) generál egy munka- 
lapot, melyre kiírja az összes oda tartozó adategységet. Ezek a munkalapok a kódok kontrolljának eszközei. Azok segítségével végezzük a kódok „jóságának" vizsgálatát.

A program a kódszóval való egyezést keres, vagyis az azonos kód nem feltétlenül jelent tartalmi egyezést. Ezért a kódkiosztás után minden esetben ellenőrizzük, hogy azonos jelentésű adategységek kerültek-e az egyes kódok alá (egy csoportba, egy munkalapra), elemezzük, értelmezzük a munkalapok adategységeit és kiemeljük, átkódoljuk a tartalmukban oda nem illőket. A kódok finomításához, a jelentésüket, tartalmukat tekintve „kakukktojások” kiszüréséhez megvizsgájuk, hogy az adott kód (kulcsszó) milyen más kulcszszavakkal jelenik meg. Ez nem túl sok adategység esetén manuálisan is elvégezhető, de szoftveres támogatást is használhatunk. Erre példát az „Ön szerint milyen negatív hatása lehet az IKT-eszközök használatának óvodás korban?" kérdésre adott válaszok 'Játék' munkalapjának EKOD-dal való elemzésével mutatunk be.

A „játék” a második leggyakoribb szó az IKT-használat negatív hatásaira irányuló kérdés válaszaiban, a kódolás 275 adategységet rakott ki a „Játék’ munkalapra. Arra voltunk kíváncsiak, hogy a „játék” szó milyen tartalmi összefüggésben, milyen más kulcsszavakkal van jelen. Ehhez átírtuk a valaszokKodolasa' makrót. Töröltük a statisztika készítésére és az új munkalapok generálására vonatkozó parancsokat, és beállítottuk a kódok jelenítésének helyét. Módosítottuk a „kodok” munkalapot, töröltük „játék” rekordját, hiszen azt már tudjuk, hogy az szerepel az adategységekben. Az átállítások után lefuttatva a makrót, azt találtuk, hogy „játék” szó az adategységek valamivel több, mint felében (147) egy másik, a kódolásban használt kulcsszóval együtt szerepel. A „kodok” munkalapon DARABTELI függvény ${ }^{10}$ segítségével megszámoltuk azok gyakoriságát. A „játék” mellett az alábbi kulcsszavak fordultak elö gyakran: „idö" (a 275 találat 4,0\%-a), "gyermek” (10,9\%), „elveszi” (8,7\%), „elvon” (8,7 \%), „mozgás” (6,5\%), az „agressziő” (5,5\%), „tud” (4,0\%), a "társas" (4,0\%), „néz” (3,6\%), „függ” (3,6\%).

Kézzel megvizsgálva a különböző kulcsszópárokat tartalmazó adategységeket, azt látjuk, hogy a játék szó döntően két vonatkozásban van jelen az IKT-használat negatív hatásairól szóló szülői vélekedésekben, jellemzően a hogyan vagy a mit kontextusában említik azt. A válaszadók egy része, lényegében azt fogalmazza meg, hogy az IKT-eszközök használata háttérbe szorítja a hagyományos játékokat, elveszi az időt, elvonja a gyermekeket a mozgásos, a csoportos társas játékoktól. (4. ábra) Az adategységek részleteikben különböznek a másik kulcsszótól függően. Ilyen például a „játék”-„gyermek” pár esetében, hogy a hagyományos játék hiánya a fejlődés rovására megy. Vagy például a gyermekek már nem tudnak hagyományos társasjátékokat játszani (,játék”-,tudás”). A „játék”-,idő” pár a „nézés” kulcsszóval együtt

${ }^{10}$ https://support.microsoft.com/hu-hu/office/darabteli-f\%C3\%BCggv\%C3\%A9ny-e0de10c6f885-4e71-abb4-1f464816df34 (A szerk.) 
is megjelenik, abban az értelemben, hogy a gyermekek túl sok időt töltenek a képernyő előtt, ha a szülő nem korlátozza azt. Ketten jelezték, hogy nem tudnak (nem ismernek) negatív hatást, de inkább a szabad levegőn végzett hagyományos játékokat szorgalmazzák.

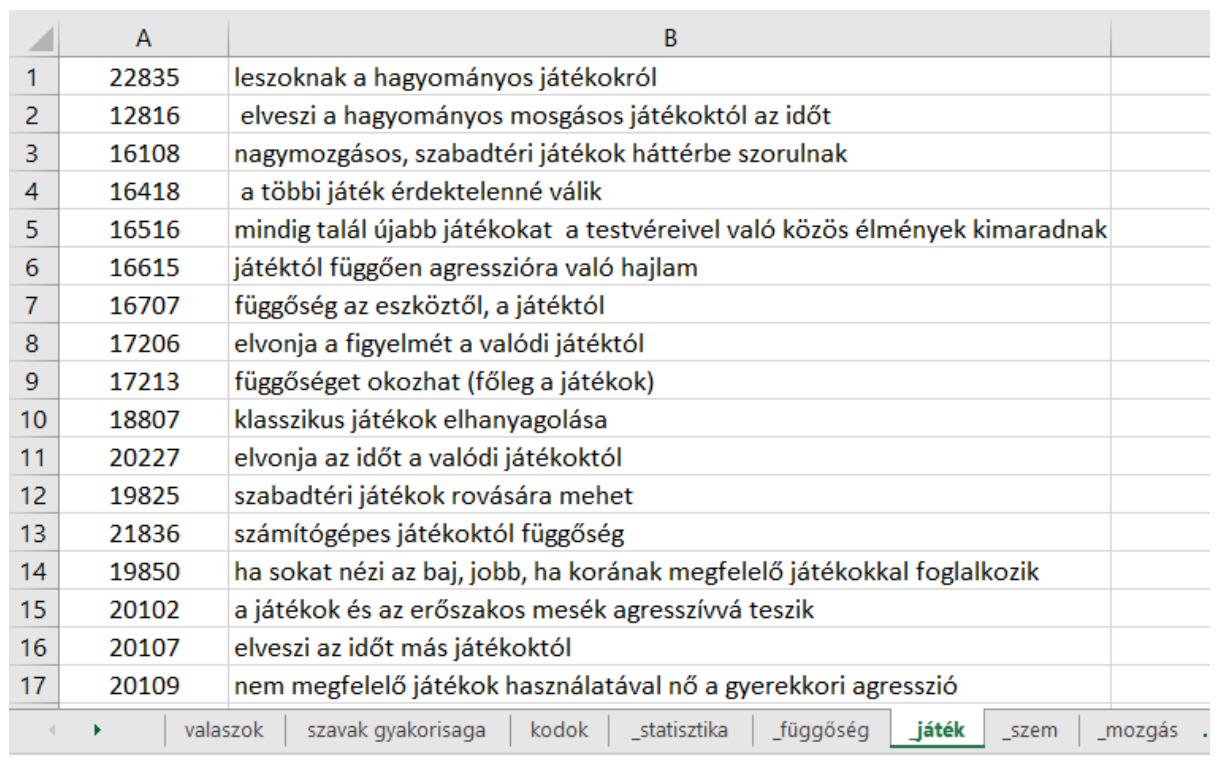

4. ábra

Az „Ön szerint milyen negatív hatása lehet az IKT-eszközök használatának óvodás korban?" kérdés kódolásához generált ,játék' munkalap részlete.

A kérdés kapcsán nyilatkozó szülők másik csoportja arra fókuszált, hogy milyen negatív hatásai lehetnek vagy vannak az IKT-eszközök használatának. 5,5\%uk számítógépes játékot az agresszióra való hajlammal kapcsolta össze, ők úgy vélik, hogy a nem megfelelő játékok használatával nő a gyermekkori agresszió (lásd még 4. ábra 15., 17. sor). Vannak, akik (3,6\%) az IKT-eszközön való játék veszélyét a függőség kialakulásában látják. Mások $(2,2 \%)$ úgy gondolják a számítógépes játékokkal való játék a személyes kommunikáció, a kapcsolatok háttérbe szorulásához vezet (a játék mellett a másik kulcsszó a „szem”).

Az elemzés szerint a csak ,játék” kulcsszót tartalmazó adategységek az általunk felállított kulcsszavak nélkül, de lényegében ugyanarról szólnak, mint az előzőekben leírtak. Utalnak arra, hogy a gyermekek nem tudnak játszani hagyományos játékokkal, nem mozognak eleget, lemaradnak a fejlődésben. Említik a társas kapcsolatok hiányát, a függőség kialakulását, a nem megfelelő tartalmakat és a valós és virtuális világ összemosódását. Új tartalomként az IKT-eszközökkel való játék miatt fellépő érdektelenség jelent meg. 
A "Játék" munkalap elemzésével képet kaptunk arról, hogy a megkérdezettek milyen negatív hatást tulajdonítanak az IKT-eszközökön való játéknak. A tartalomvizsgálat ugyanakkor kódolási problémát jelzett: megmutatta, hogy a jelentésüket tekintve különböző adategységek kapták ugyanazt a "játék" megnevezésű kódot. Vagyis ugyanazok a tartalmak több csoportban, esetünkben több munkalapon is ott vannak (például „függőség az eszköztől, a játéktól" adategység a "függőség" és a "játék" kód alá is tartozhat). A kódolás egyik alapszabálya, hogy egy adategységhez csak egy kód tartozhat. Ezért el kell döntenünk, hogy melyik kódot kapja a több helyre besorolt egység. A kérdéses adategység abba a csoportba kerül, amelyikbe tartalmi jelentését tekintve leginkább illeszkedik. Például a „Függőséget okozhat (főleg a játékok)” adategységben két kulcsszó van, a „játék" és a „függőség”. A "Játék" munkalap elemzése során láttuk, hogy a legtöbb szülő az IKT-eszközökkel való játék nem kívánt hatásaként a hagyományos, társas játékoktól való elfordulást, a kevés mozgást, a társas kapcsolatok hiányát említette. Veszélyként azonosították az agresszív játékok, az agresszív tartalmak használatát. A '_függöség' munkalapon lévő adategységeket vizsgálva kiderül, hogy azokban a függöség példánkhoz hasonló jelentéssel bír. Például: „Az agy dopaminközpontját ingerli, függőség alakul ki.” vagy „Ha nincs korlátozva a használati idő, függőséghez vezethet." Vagyis a példa adategység a „függőség” kód alá kerül, tehát manuálisan töröljük a "Játék” munkalapról. A következő „Az agresszív verekedős játékoktól állandó versengés" adategység esetében megtartottuk a ,játék” kódot. Részben, mert az a játék jelzője, részben, mert a válaszadók többsége az agressziót a gyermekek viselkedésével kapcsolatban, annak jelzőjeként használta.

Mint az eddigiekből kiderül, a kvalitatív adatfeldolgozás legmunkaigényesebb és leghosszabb szakasza a kutatási kérdésnek megfelelő kódok megtalálása és azok adategységekhez rendelése volt. A végső, „tiszta” (azonos, de legalábbis igen hasonló jelentésü adategységeket jelölő) kódokhoz a fent bemutatott kódszótárkészítés - kódolás - ellenőrzés műveletek többszöri végrehajtásával jutunk. Az első kódlista rendszerint a szógyakoriság alapján készül, jellemzően a leggyakoribb, illetve a téma szempontjából relevánsnak ítélt szavakból. A program formai, a keresőkifejezéssel való egyezés alapján osztja ki a kódokat, vagyis azok különböző tartalmakhoz tartozhatnak. Ezért az egy kód alá tartozó adategységek manuális „jóságvizsgálata”, a jelentésbeli, tartalmi egyezőség ellenőrzése általában felülírja azok egy részét. Ez történt például a fent elemzett „játék” kóddal. Mint láttuk, a „játék” kódú adategységek többsége vagy arról szól, hogy az IKT-eszközön való játék hogyan fejti ki negatív hatását (például elvon valamitől), vagy arról, hogy milyen nem kívánt változást okoz (például agresszív viselkedést). A „játék” kódot kivettük a kódszótárból, és az utóbbi esteben az adategységek a tartalmuknak megfelelő változáshoz tartozó kódot kapták, a példánknál maradva ez az „agresszió”. Az első csoport egységei a „von” kód alá kerültek. Annak vizsgálata ugyanis azt mutatta, hogy azok, tartalmukban inkább illenek oda. Abban 
a csoportban például olyan válaszok találhatók, mint „Elvonhatja az időt a valódi élettől.”, „Elvonja a gyermeket a társaktól.”.

A kódok adategységeinek ellenőrzésekor rendezzük, szelektáljuk a kódokat. Ennek a folyamatnak a során egyrészt a kódszótár folyamatosan finomodik, kódok törlődnek és újabbak kerülnek a listába, egy-egy kódhoz több, összetettebb keresőkifejezést kapcsolunk. Másrészt a kódoló „megtanulja” a kódokat, képes lesz döntést hozni arról, hogy egy-egy kulcsszó milyen vonatkozásokban, milyen értelmezésekben van jelen az adatkorpuszban. Ez szükséges a fókuszelemzéshez, az adategységcsoportok integrálásához, a kategóriarendszer felállításához. A kvalitatív elemzésekre alkalmas szoftverek különböző szinten, mértékben gépesítik a kódolást, de egyik sem működik emberi közreműködés nélkül, különösen nem az induktív elméletépítés során használt nyílt kódolás. Az elemző programok adta lehetőségek, ha korlátozottabban is, de használhatók, ahogy mi is tettük az EKOD kidolgozásával és alkalmazásával.

\section{A tapasztalatok összegzése, a továbblépés lehetőségei}

A kvalitatív adatok feldolgozása az empirikus vizsgálatok kritikus mozzanata (Gelencsér, 2014; Szokolszky, 2004), ahol nem könnyü feladat a tudományos kutatás kritériumainak teljesítése. Az adatfeldolgozás során az érvényesség, a megbízhatóság és az objektivitás biztosításában nagy előrelépést jelentett az infokommunikációs technológiák bevonása. Noha a kutatások évtizedek óta használnak különböző IKT-alkalmazásokat, a kvalitatív adatfeldolgozásnak nincs univerzális módszere (Cisneros et al., 2012; Dömsödy, 2014; Sánta 2017), minden kutatáshoz meg kell találni a leginkább illeszkedőt. Ezzel a problémával szembesültünk az „IKT-eszközök használata óvodáskorban” kutatás nyílt tételeinek feldolgozásakor, a szülők percepcióinak és preferenciáinak kódolásakor. A kérdőív kvalitatív adatait nyílt, számítógéppel támogatott kódolással dolgoztuk fel, melynek elméleti keretet a GT-módszer adott. A kódszótárkészítést és kódok kiosztását saját Microsoft Excel programban írt makrócsomaggal végeztük, amit EKOD-nak neveztünk el.

Az EKOD, miután az adatkorpusz Excelben készült, az adatokat tartalmazó állományban fut. Egyetlen munkalapra felvéve a kódokat, egyetlen program futtatásával elkészíti az összes kódot. Az elérhető szoftverekben egyesével kell a szótár elemeit, a szabályokat felvenni, majd a kódolást minden elemhez külön-külön kell futtatni, jelentősen növelve a kódoláshoz szükséges időt és munkamennyiséget.

Az EKOD három részből áll, a ,vizsgalSzogyakorisag, a ,valaszokKodolasa' és a ,torolElozoFutas' nevü programból. A ,vizsgalSzogyakorisag' makró az adategységekben előforduló szavak gyakoriságát vizsgálja és listázza gyakoriság szerint növekvő sorrendben. Szemben az ingyenesen elérhető programokkal azonosnak tekinti a szavak megadott alakjait (például „gyermek”, „gyermekek” „gyerek', „gyerekek”) és azok találatainak összegét írja ki. A ,valaszokKodolasa' 
makró a szógyakoriság-vizsgálat alapján összeállított szótárat használva végzi a kódolást. Jelöli a válaszok mellett a tartozó kódszámot és kódszót, továbbá minden kódszóhoz egy munkalapot generál, és azon összegyüjti az adott kulcsszóhoz tartozó adategységeket. A makrók használatának nehézsége, hogy a kiadott parancs nem vonható vissza, ezért készült a ,torolElozoFutas' program, a kódolás törlésére.

A makró használata egyszerü, nem igényel elmélyült informatikai ismereteket. A makró megírása, különböző igényekhez igazítása gyorsan megtanulható. Az EKOD a beállítások átállításával, a keresőkifejezések átírásával könnyen adaptálható más kutatásokhoz, az azonos szerkezetü, azonos felépítésü ${ }^{11}$ adattáblák kódolásához.

Több szoftver ingyenes próbaverziójának kipróbálásakor néha elég bonyolult menürendszerekkel találkoztunk, és eligazodni sem volt könnyü bennük - szemben az Excel egyszerübb menürendszerével.

Az „IKT-eszközök használata óvodáskorban” kutatás kvalitatív adatainak feldolgozása során hasznos segítség volt az EKOD, amit a kódolás során folyamatosan fejlesztettünk. Használata megkönnyítette és lerövidítette a kódszótár készítését, emellett lerövidítette az ellenőrzést, a kódok jóságának vizsgálatát. Megítélésünk szerint a program jól működött, de használatakor szem előtt kell tartani a következőket: korlátozott adatmennyiséget tud kezelni, a makrót minden elemzett adattáblához hozzá kell adni, és a kiadott parancs nem vonható vissza, törölni makróval lehet. Ezért javasolt a feldolgozandó adattáblákról másolato(ka)t készíteni.

Az EKOD alkalmazásával végzett kódolás fontos tapasztalata, hogy az áttekinthetőség érdekében változtatni kell az adattábla szerkezetén. A kódolást olyan adattáblákban végeztük, amelyekben egy sor egy kitöltés (egy válaszadó adatai), a sor cellái az adategységek. Az EKOD a kódokat és a kódszavakat az adategységek melletti oszlopokban jeleníti meg. Mivel az egyes kitöltések változó számú adategységből állnak, különböző hosszúságúak, így nehezen áttekinthető táblát kaptunk. Ezt megoldandó javasolt az adattáblát úgy átrendezni, hogy egy sor egy adategység legyen. Az EKOD-ot egy ezt végrehajtó makróval kell továbbfejleszteni.

Az automatizálás lehetősége Excel-platformon korlátozott. Az EKOD további bővítésével azonban csökkenethető a „kézi munka”, tovább rövidíthető a kódolás időtartama. Az egyik lehetséges továbblépés, hogy munkalapok adategységeinek elemzésekor megjelöljük az azonos jelentésü adategységeket, egy makró segítségével az összes munkalapról egyetlen munkalapra öszszegyűjtjük az azonos kódokat. Így „azonnal” ellenőrizhetővé válik a kódok javítását célzó hipotézisünk.

\footnotetext{
${ }^{11}$ Ahol azonos az oszlopelnevezés, a sorrend, azonos típusú adatok vannak az oszlopokban.
} 


\section{Irodalom}

Aldhafeeri, F. M. \& Palaiologou, I. (2016). Interactions with digital technologies of children from 3 to 6 in Kuwaiti homes, E-journal of the British Education Studies Association, 7(3), 48-68.

Arnott, L. (2013). Are we allowed to blink? Young children's leadership and ownership while mediating interactions around technologies, International Journal of Early Years Education, 21(1), 97-115. https://doi.org/10.1080/09669760.2013.772049

Bodor P. (2013, Ed.). Szavak, képek, jelentés. Kvalitatív kutatási olvasókönyv. L'Harmattan.

Charmaz, K. (2003). Grounded Theory: Objectivist and Constructivist Methods. In N. K, Denzin, \& Y. S. Lincoln (Eds.), Strategies of Qualitative Inquiry (pp. 249-291). Sage Publications.

Charmaz, K. (2006). Constructing Grounded Theory. A Practical Guide through Qualitative Analysis. Sage.

Charmaz, K. (2008). Grounded Theory. In Smith, J. A. (Eds.). Qualitative Psychology. A Practical Guide to Research Methods (pp. 81-110), Sage.

Cisneros Puebla, C.A., \& Davidson, J. (2012). Qualitative Computing and Qualitative Research: Addressing the Challenges of Technology and Globalization. Forum Qualitative Sozialforschung / Forum Qualitative Social Research, 13(2). http:// nbn-resolving.de/urn:nbn:-de:0114-fqs1202285

Corbin, J., \& Strauss, A. L. (1987). Accompamments of chronic illness: Changes in body, self, biography, and biographical time. In J. A. Roth \& P. Conrad (Eds.), Research in the sociology of health care: Vol. 6. The experience and management cif chronic illness (pp. 249-281). JAI Press.

Corbin, J., \& Strauss, A. L. (1990). Grounded theory research: Procedures, canons, and evaluative critena. Qualitative Sociology, 13(1), 3-21.

https://doi.org/10.1007/BF00988593

Corbin, J. \& Strauss, A. (2015). A kvalitatív kutatás alapjai. L’Harmattan Kiadó.

Couse, J. \& Chen, D. (2010). A Tablet Computer for Young Children? Exploring its viability for early childhood education, Journal of Research on Technology in Education, 43(1), 75-98. https://doi.org/10.1080/15391523.2010.10782562

Dömsödy, A. (2014). A számítógéppel segített számítógépes adatfeldolgozás néhány módszertani kérdése. In Szabolcs, É. \& Garai, I. (Eds.) Neveléstudományi kutatások közbe - válogatás doktori hallgatók munkáiból. (pp. 18-27), ELTE Pedagógiai és Pszichológiai Kar.

Ehmann B. (2002). A szöveg mélyén. A pszichológiai tartalomelemzés. Új Mandátum.

Fontana, A. \& Frey, J. H. (2005). The interview: from neutral stance to political involvment, In Denzin, N. K. \& Lincoln, Y. (Eds.), The handbook of qualitative research, 3rd edition, (pp. 695-727), Sage. 
Geer, J. G. (1991). Do open-ended questions measure "salient" issues? Public Opinion Quarterly, 55(3), 360-370. https://doi.org/10.1086/269268

Gelencsér, K. (2003): Grounded Theory. Szociológiai Szemle, 13(1), 143-154.

Giorgetti, D. \& Sebastiani, F. (2003). Automating Survey Coding by Multiclass Text Categorization Techniques. Journal of the American Society for Information Science and Technology, 54(14), 1269-1277.

https://doi.org/10.1002/asi.10335

Glaser, B. G. \& Strauss, A. L. (1967). The Discovery of Grounded Theory: Strategies for Qualitative Research. Aldine.

https://doi.org/10.1097/00006199-196807000-00014

Glaser B. G. (1992). Basics of grounded theory analysis. Sociology Press.

Glaser, B. G. (1978). Theoretical Sensitivity: Advances in Methodology of Grounded theory. Sociology Press.

Glaser, B. G. (1998). Doing Grounded theory: Issues and Discussion. Sociology Press.

Glaser, B. G. (2004). Remodeling Grounded Theory. Forum Qualitative Sozial forschung / Forum: Qualitative Social Research [On-line Journal], 5: 80 paragraphs. http://www.qualitative-research.net/fqs/fqs-eng.htm (2019. 12. 19.)

Hódi, Á., Tóth, E., B. Németh, M., \& Fáyiné Dombi, A. (2019). Óvodások IKThasználata otthon - szülői minta és szerepvállalás. Neveléstudomány, 6(2) 22-41. https://doi.org/10.21549/NTNY.26.2019.2.2

Holloway, D., Green, L., \& Livingstone, S. (2013). Zero to eight. Young children and their in-ternet use. EU Kids Online.

Holton, J. A. (2010). The Coding Process and Its Challenges, The Grounded Theory. Review, 9(1), 21-39.

Kincsei, A. (2007). Technológia és társadalom az információ korában. In Pintér, R. (Ed.) Az információs társadalom: az elmélettöl a politikai gyakorlatig: tankönyv (pp. 47-63), Gondolat - Új Mandátum.

Kucsera, Cs. (2008). Megalapozott elmélet: egy módszertan fejlődéstörténete. Szociológiai Szemle, (18)3, 92-108. https://doi.org/10.3167/fcl.2008.520106

Macchia, S., Murgia, M. (2002). Coding of textual responses: various issues on automated coding and computer assisted coding. Proceedings of JADT-02, 6th international conference ont he statistical analysis of textual data, (pp. 471-482).

Macer, T. (2008). WordStat from Provalis Research. Research, 508, 40-41.

Marsh, J., Kontovourki, S. Tafa, E. \& Salomaa, S. (2017). Developing Digital Literacy in Early Years Settings: Professional Development Needs for Practitioners. A White Paper for COST Action IS1410, http://digilitey.eu/wp-content/uploads/2017/01/ WG2-LR-jan-2017.pdf

Mitev, A.Z. (2012). Grounded theory, a kvalitatív kutatás klasszikus mérföldköve. Vezetéstudomány - Budapest Management Review, 43(1). 17-30.

Rácz, J. (2006). Kvalitatív drogkutatások. L’Harmattan. 
Rowe, E., \& Wong, C. (1994). An introduction tot he ACTR coding system. Automated Coding Staff Statistical Research Division, Bureau of the Census.

Sallay, V. (2015). Előszó a magyar kiadáshoz. A kvalitatív megközelítésés a Grounded Theory szerepe a társadalomtudományi kutatásokban. In Corbin, J. \& Strauss, A. A kvalitatív kutatás alapjai (pp. 9-22). L'Harmattan - SE MentálhigiénéIntézet - Sage.

Sántha, K. (2009). Bevezetés a kvalitatív pedagógiai kutatás módszertanába. Eötvös József Könyvkiadó.

Sántha, K. (2013). Multikódolt adatok kvalitatív elemzése. Eötvös József Kiadó.

Sánta, K. (2017). Számítógéppel támogatott kvalitatív adatelemzés a hazai neveléstudományi PhD-képzésben. Képzésésgyakorlat, 15(1-2), 159-174. https://doi.org/10.17165/TP.2017.1-2.9

Schounlai, M., \& Couper M. P. (2016). Semi-automated categorization of openended questions. Survey Research Methods, 10(2), 143-152.

https://doi.org/10.18148/srm/2016.v10i2.6213

Seidman, I. (2002). Az interjú mint kvalitatív kutatási módszer. Műszaki Könyvkiadó.

Strauss, A., \& Corbin, J. (1990). Basics ofqualitative research: Grounded theory procedures and techniques. CA: Sage.

Strauss, A., \& Corbin. J. (1994). Grounded theory methodology: An overview. In Denzin, N. K. \& Lincoln, Y. S. (Eds.), Handbook of qualitative research (pp. 273285). Sage.

Strauss, A. L. (1987). Qualitative Analysis for Social Scientists. Cambridge University Press. https://doi.org/10.1017/CBO9780511557842

Strauss, A. L., \& Corbin, J. M. (1998). Basics of Qualitative Research: Techniques And Procedures for Developing Grounded Theory. Sage Publications.

Szokolszky, Á. (2004). Kutatómunka a pszichológiában. Osiris Kiadó.

Vandewater, E. A., Rideout, V., Wartella, E. A., Huang, X., Lee, J. H., \& Shim, M. (2007). Digital Childhood: Electronic media use among infants, toddlers and preschoolers, Pediatrics, 119: e1006-e1015. https://doi.org/10.1542/peds.20061804

Vicsek, L. (2006). Fókuszcsoport. Elméleti megfontolások és gyakorlati alkalmazás. Osiris.

Viechnicki, P. (1998). A performance evaluation of automatic survey classifiers. In Honavar, V. \& Slutzki, G. (Eds.) Proceedings of ICGI-98, 4th international colloquium on grammatical inference, Ames, IA (pp. 244-256). Springer verlag. Published in the "Lecture Notes in Computer Science” series, number 1433. https://doi.org/10.1007/BFb0054080 


\section{B. Németh, M., Juhász, F, Hódi Á., \& Tóth, E.}

\section{ICT use among kindergarten aged children - encoding the open ended items of a survey with the EKOD macropackage}

When we set out to study pedagogical situations, in certain cases the use of constructed response items is necessary. Although constructed response items provide us with a lot more information about a particular issue than their fixed choice counterparts, their use is frequently avoided because of the complexity, difficulty and time-consuming nature of the data processing. We developed an open source Excel macro (EKOD) to ease the burden on one core element of the process: coding and categorization. The aim of the present study is to analyze one open-constructed item eliciting responses about parents' views about their kindergarten-aged child's ICT use. First, we review the grounded theory used for data analysis and the methodical issues of coding. Then, we provide a detailed description of EKOD and its usability in finding keywords and establishing basic categories through the analysis of a constructed response item in the parental survey. The present work and the EKOD may assist kindergarten teachers in conducting qualitative studies and therefore contribute to a better understanding of pedagogical situations and the development of kindergarten-aged children. However, they can be applied in any qualitative study in social sciences.

Keywords: Excel macro (EKOD), grounded theory, qualitative coding, dictionary-based coding, use of ICT

B. Németh Mária: https://orcid.org/0000-0003-4978-8743

Juhász Fruzsina: https://orcid.org/0000-0002-5608-6152

Hódi Ágnes: https://orcid.org/0000-0003-0325-1449

Tóth Edit: https://orcid.org/0000-0001-9281-5730 